\title{
POLITICAL DEMOCRACY, MANAGING POVERTY AND DEVELOPMENT IN NIGERIA
}

\author{
Isiaka Hassan Aliyu, Okpoebo Casmir Chukwudi \\ Department of General Studies, Federal Polytechnic, Nasarawa, Nasarawa State, Nigeria \\ E-mail address: Isiaka93@gmail.com
}

Keywords: political democracy, poverty, development

\begin{abstract}
Poverty as an endemic factor for underdevelopment in Nigeria has drained the transitional process of Nigeria toward attaining the global advancement. Political democracy which is supposed to be a corner stone in improving the citizens welfare by its policies, has failed to meet its proffer responsibilities. Despite abundant resources, Nigeria remains among the class of under developing society and one of the poor nation in the world.

The government lost her responsibility to make effective policies that would benefit and improve the better life of the citizens. Most of the policies adopted in a bit to alleviate poverty turn to benefit only the elites while the poor continue to remain in an abject poverty.

The aims of this paper is to examine poverty, political democracy and development in Nigeria with the aim of drawing the attention of policy makers to the need to formulate a consistent poverty alleviation policy that should be backed up with consistency, political will and transparency at implementation.
\end{abstract}

\section{INTRODUCTION}

Poverty is considered to be one of the factors that bordered every nation and their leaders. Impact it is an issue that is very intimidating to human race. Poverty is among the most difficult and politically sensitive economic issue that is quit challenging to both the policy makers and the general public. The rate of poverty in the country generates an intense public concern because the effects are direct and visible.

However, every human life is surrounded by politics and as such the question of poverty can only be answered by political affairs of the nation. Politics make people rich at the same time make them poor in Nigeria. To some extend politics has become a lucrative business venture where people go for gain not for service. Generally, Nigeria is blessed with abundant resources whereas nobody should lack anything as regard to shelter, food, employment and other necessities of life. But in Nigeria the reverse is the case. People live in abject poverty where the rich become richer while the poor become poorer.

Political democracy is a process that allowed citizens to choose among competing candidates and also the freedom to have effective and functional rule of law. In achieving this, citizens will have confidence in policies of governance that will lead to development. Development is a change in social structures, political attitudes and national institutions as well as acceleration of economic growth, reduction of inequality and eradication of absolute poverty (Mato, Jacob,And Akintola, 2011).

Poverty is one of the main symptoms or manifestations of underdevelopment and its reduction is generally considered synonymous with development (ifamose, 2001). The existence of poverty in the particular society therefore reflects the state of the development of an economy and its management. Alleviation of poverty is a social indicator of development; the basic need for development to take place. Poverty can be determined by individual motivation, aptitudes, bad leadership and lack of revolutionary consciousness. Poverty alleviation is a political issue that requires a political solution. 


\section{CONCEPTUAL CLARIFICATION POVERTY}

Poverty affects many aspect of human condition including physical, moral and psychological. Therefore, poverty is defined in various ways depending of scholars perceptions. Poverty is more recognized than defined (Aboyade, 1975:25). Barrett (2003) defined poverty as a situational syndrome which combined under-consumption, law educational level, malnutrition, precarious housing condition, bad sanitary condition, unstable participation in production system or restriction to it more primitive strata, attitude of discouragement and anomie, little participation in the mechanism of societal integration and possible adherence to a particular scale of values different to some extent from those held by the rest of the society. Poverty is inability to gain access to basic necessities of life, such as food, decent shelter, clothing, and so on and inability to fulfill basic economic and social obligations (Olasupo, 2010). According to sociological research driven by Wilkins (1984) as cited in Olasupo (2010:108) the poor infrastructures, health, nutrition, selfesteem, low hygienic standards, intellectual development, and lack of capacity to articulate social, economic and political environment and low per capita income are the manifestations of poverty.

Narayan et al (2000:30) defined poverty in relation to what constitute poor. He sees poverty as humiliation, the sense of being dependent, and of being forced to accept rudeness, insults, and indifference when we seek help. Another of such views of the poor is that expressed by a poor man in Kenya in 1997 as reported by Narayan et al (2000:30) thus:

"Don't ask me what poverty is because you have met it outside my house. Look at

the house and count the number of holes. Look at my utensils and the clothes that I

am wearing. Look at everything and write what you see. What you see is poverty."

The above reflect just descriptions of a few of the various perceptions of poverty at least from the poor. Poverty could denote a state of deprivation as was captured by Nigeria's Federal Ministry of Economic Co-operation and Development (1992:3) as "not having enough to eat, a high rate of infant mortality, a low life expectancy, low educational opportunities, poor water, inadequate heath care, unfit housing and a lack of active participation in the decision making process". It could also denote "absence or lack of basic necessities of life" or "lack of command over basic consumption needs such as food, clothing and or shelter", "glaring defects in the economy, etc"

Omodia (2007) categorize poverty in terms of political, economic, social, ideological and technological. He opined that lack of individual or group to participate meaningfully in the society, is political poverty. Whereas individual or group discriminated against on the basis of social status is social. It is economic when the individual or group is not able to satisfy the basic need. The ideological is lack of autonomy for development and technological is when society survives on primitive productive capacities. Generally, poverty is the inability to achieve certain minimal standard of living. Obadan (1997) further categorizes poverty in terms of chronic/ structural or conjectural/transient poverty. Chronical/structural is long-term and more permanent. It is cause by locational disadvantages, limited productive resources, endemic socio-political, cultural factors, and lack of skills for gainful employment. While on the other hand, transient/conjectural poverty is cause by natural disaster such as drought, typhoon/flood or man-made disasters like wars, environmental degradation and structural adjustment reforms. Poverty may also be conceived of as absolute poverty or relative poverty. Aliyu (2003:2) explained absolute poverty conditions where an individual or group of people lacks basic requirements such as education, health, housing, feeding employment, and transportation. Absolute as described by Aboyade (1987:7) is a total lack of necessities and facilities like food, housing, medical care, education, social and environmental service, consumer goods, recreational opportunities, neighbourhood amenities and transport facilities. It is a basic fact that what is considered poverty level in one country or community may well be the height of well-being in another. Relative Poverty, according to Aliyu (2003:2) is a situation where an individual or group of people can be said to have access to his/their basic needs, but is comparatively poor among persons or the generality of the community. To Aboyade (1987:7) relative poverty occurs when people are poverty-stricken when their incomes, even if adequate for survival, fall radically behind that of the community average, they cannot have what the larger community regard as the minimum necessary for decency, and they cannot wholly escape therefore 
the judgment of the larger community that they are indecent. They are degraded, for in the literal sense, they live outside the grades or categories which the community regards as acceptable."

\section{DEVELOPMENT}

Development has no precise meaning. V.I. Lenin (1968) defined development as a progressive movement; an ascension from lower to higher stages; and from simple to complex situation. Rodney (1972) sees development as ability of a man to conquer his environment and utilize it to his advantage. The process involves the development of tools, skills, and the mobilization of required resource for development purpose. Development is a transformation that will lead to general improvement in the quality standard of living of the people via eradication of poverty, hunger, disease, unemployment and others problems (Alanana, 2012). Development is changes in political attitudes, social structure, reduction in poverty, inequality, as well as acceleration of economic growth (Mato, Jacob, and Akintola, 2011).

Goodwin and Otuya (2009:17) maintain that development has to do with sustenance ( ability to meet basic needs), high self-esteem(to be person), freedom from servitude ( to be able to choose) and ability to reach one's full potentials(be what one wants to be /achieve what one wants to achieve. Praetor (1970) argued that any definition of development must address factors affecting human lives. Therefore, seer (1972) sees development as absence or total elimination of poverty, unemployment, and inequality. Until these are adequately address and redress that society cannot claim to be developed. These means that any effort made to get rid of these problems translates to improvement in the quality of life and standard of living of members of a given society. Development enhances democracy. Democracy can be firmly rooted when there is reasonable level of development (saliu, 2010).

\section{POLITICAL DEMOCRACY}

There where series of argument amongst the political analysts and theorist on the existence of true or pure democracy in our contemporary societies (ifamose, 2001). It has argued that most of its ideals are not practice in accordance to democratic principles. Particularly in Nigeria, people are dominated and alienated from democratic freedom. To this, Marx argued that democracy within a capitalist society is a ruse. Democracy is class based (Ifamse, 2001).

Democracy entails the harmonious relationship among the democratic institution in the best interest of the electorate who has transferred their sovereign powers to the institution of government (saliu, 2010). The main essence of democracy is to establish social order, promoting the general welfare of the people. This will go a long way in reducing conflicts among the people thereby improving the political stability of the nation. Pure democracy brings about political stability and reduction in poverty. There is no society that will develop when its citizens are in object poverty. The incorporation of African societies into the global capitalist was in nature accepted due to the fair of poverty. Contrary to this, some scholars with radical tradition defined development in terms of ability of a country to hold her together against the invading capitalist system. But to some extent, the African societies were more at receiving end where their resources were drain to the advantages of their various colonial masters. This affects democracy and development in their leadership style, political ideology and structural stagnation. Poverty at end becomes a permanent feature of the Nigeria society because of insufficient management and corruption at every level of government.

However, with the nature of high level of poverty in Nigeria, democracy remains enemy to national development. To this, democracy is an impediment to Africa and Nigerian development. Political democracy remains the major factor for political underdevelopment of Nigeria do to its failure to address issues of corruption, political extravagance, and abuses of doctrine of equality and as such poverty become the dominant factor of democratic underdevelopment of the Nigerian people. 


\section{POVERTY IN NIGERIA}

Poverty is a rural phenomenon (Okunmadewa, 1997:297). Poor in Nigeria lack accessible roads, access to productive inputs as well as output markets, hunger, ill- health, inadequate or poor housing, illiteracy, malnourishment and food insecurity.

Todaro (1985) perceives poverty as the people living below a specified minimum level of income. World Bank Human Report (2001) has pegged \$1 per day as poverty line. Even though, this has been criticized by Uke (2012), the poverty line fails to reflect the peculiarities of various communities and nations. Ajakaiye (1999) further explain that poverty in one region is not only a problem to that region, but also to the world.

In most African societies and Nigeria, poverty is visible through its indices such as overcrowded settlements in major urban areas without basic social services and isolated rural areas major concentration of the poor. In 1993, an estimated $40 \%$ of the people in sub- Sahara Africa (SSA) lived on less than one dollar a day. At least $50 \%$ of these people were from five east African countries and Nigeria. Nigeria at $60 \mathrm{~s}$ the first republics $5.98 \mathrm{~m}$ out of $37.41 \mathrm{~m}$ Nigerians, $16 \%$ of the populations were poor. By second republic the poverty has moved to $28.1 \%$ these by implication about $15.57 \mathrm{~m}$ were poor out of $86.72 \mathrm{~m}$ Nigerians. In 1996 the poverty level has jumped to $65.5 \%$ constituting about $69.56 \mathrm{~m}$ of the estimated population of $106.26 \mathrm{~m}$ Nigerians. After the return of democracy 1999, the country's human development index (HDI) was as low as 0.416 and the poverty level was as high as $70 \%$ of the population of about $116.11 \mathrm{~m}$, meaning that 81.28 were poor (Uke, 2012). Nigeria was placed among the 23 poorest nations in the world (HDI, 1999). In addition, in measuring life expectancy, literacy and standard of living after ten years into democracy, Nigeria rank $158^{\text {th }}$ out of a total of 182 countries and placed 24 poorest nations in the world by human development index.

According to the 2005 Millennium Development Goals of the United Nations development programme, the proportion of people living below the national poverty line declined from $65.6 \%$ in 1996 to $54.4 \%$ in 2004 . This means out of estimated population of 134.63 Nigerians 73.24 were still poor. This gives a declining poverty rate of $17.1 \%$ over a period of 11 years (Uke, 2012).

TOZALI, the eyeliner magazine, attested that, at $21^{\text {st }}$ century, 1.2 billion people live in object poverty. More than 800 million people go to bed hungry and 50,000 people die every day from poverty - related causes. In Nigeria; according to the report of the Nigerian bureau of statistic, published on the Nigerian tribune dated $13^{\text {th }}$ February 2013, the percentage of Nigeria living in absolute poverty - those who can afford only the barest essentials of food, shelter and clothing rose to $60.9 \%$ in 2010 , as compared with $54.7 \%$ in 2004 and recently, there is fear that the percentage of poverty might have risen to $71.5,61.9$ or $62.8 \%$ in 2012 . This poverty level transmitted from generation to generation. Most of the affected people are the young children, pregnant mothers, the elderly, rural area, and marginal urban zones and those groups of people who have not been integrated into their own society and among the world are those who lack resources and capacity to organize themselves to achieve meaningful development by way of agitating hash government policies. (Obadan, 1997).

This is in spite of the fact that the country is richly endowed with all kinds of water, agricultural and mineral resources. Nigeria's proportion of the poor has doubled over the last two decades, during which time the country received over $\$ 300$ billion in oil and gas revenue. Paradoxically, Nigeria's level of revenue and endowment are in opposite direction with her poverty level. While revenue profile of Nigeria rose from N4 billion in 1975 to N26 billion in 1980, and GNP per capita rose from $\$ 360$ to more than $\$ 1000$ in the same period, the percentage of the population that was poor grew from $15 \%$ in 1960 to about its present $70 \%$. Furthermore, according to World Bank and UNDP 2001 statistics, Nigeria which impressively ranked 6th and 7th in Petroleum Export and Petroleum Production respectively, is ranked 194th in GNP per capita and is unenviably classified as the 25 th poorest nation in the world. 
More disturbing is the fact that despite the massive amount of resources committed to those programmes, the poverty situation aggravates, more and more people fall into the poverty region instead of escaping.

\section{CAUSES OF POVERTY AND ITS EFFECTS IN NIGERIA}

The blame for high rate of poverty situation in the country is shifted to two different angles, which are on perspective of government and as well on the side of individuals.

In the first instance, the wrong application of government functions and policies made it difficult for people to be free from shocks of poverty. It has been noted that a greater percentage of the Nigerians population lives in rural areas and little or no attention is given to them by any government to enhance their living conditions instead huge promises were made which never saw the light of the day.

Consequently, these rural dwellers suffer from lack of basic facilities of life ranging from inadequate nutrition, poor housing, clothing and shortage of water supply to an ever deteriorating state of healthcare delivery facilities and road network. To support this fact, Kure (2002) observed that rural areas, therefore, suffer total neglects with respect to the above mentioned facilities and as a result, able youth migrate massively to the urban areas resulting to low productivity on the agricultural sector that is supposed to sustain the provision of food to the populace and inputs to agro- allied industries. The neglect resulted into food security and this translates into high cost of agricultural products.

The preference given to oil by the government without attention to the agriculture led to the suffering of Nigerian larger population. The neglect of agriculture has done more harm to the rural people because most of them depend on subsistence farming which is not yielding profitable results. Government promises of fertilizer and others input become unrealizable.

Culture promotes poverty to a large extent in our country. The cultural practice of extended family often creates hardship on a given family that is looked upon as doing fine. In such a situation others member of such family even those are far related, rely on that family for financial assistance so that little income which is expected to take care of the immediate family is shared among far related family members subjecting that family to poverty.

Lack of saving culture among Nigerians is one of the causes of poverty in the country. There is a higher propensity to consume than to save because they consider their income to be smaller than their expenditure and believe it is impossible to save what you do not have.

More so, it is pertinent to note that most government policies are biased toward the poor. Adequate attention and assistance in terms of relief is not paid to victims of natural disasters, like flood, droughts, fire outbreaks, accidents and man -made disaster such as wars, communal clashes, religious and political riots. All these subjected peoples to poverty as their resources are destroyed and the hope of acquiring it back may however be elusive.

The poor also help in impoverishing themselves; this is because they lack the courage and collision to demand for their rights. They are therefore abandoned economically, politically, socially, culturally Galadima (1999). Lack of adequate payment of gratuity and pension to retired public servant who have served the government in different capacity worsen poverty situation in Nigeria. Most of these retirees relied on their benefit to meet desired need, failure of the government to promptly paid them result to a large extent public demonstration, violence and even involve into criminal activities. Crime and violence cannot be isolated when discussing the cause of poverty. A continuous increase in crime and violence has reduced the quality of life to a great extent, individuals of all socio-economic groups are affected and the urban poor are vulnerable to these social problems.

Crime and violence have serious economic effects especially on employers' resources or investors. The greater proportion of public resources which are already limited is required to strengthen police force, support the growing prisons population, finance the demand of judicial system and also aids those affected by violence. Little or no resources are left in order to employ human or other 
resources for productive venture or social services provided by the government (Ajakaiye and Adeyeye, 2001)

To add to the above causes of poverty, the World Bank Poverty Task Force In 1999 as cited in Uke (2012) come up with the causes of poverty.

1. Inadequate access to the means of supporting rural development in poor regions.

2. Low endowment of human capital.

3. Inadequate access to assistance for those living at the margin and those victimized by transitory poverty.

4. Inadequate physical asset, such as land and capital and minimal assess by the poor to credit, even on a small scale.

5. Inadequate access to employment opportunities.

6. Inadequate access to markets where the poor can sell goods and services.

7. Lack of participation; failure to draw the poor into the design of development.

8. Destruction of natural resources, leading to environmental degradation and reduce productivity.

Bamidele (1997) expanded the literature of causes of poverty as lack of access to basic needs/goods, productive resources, inefficient use of common resources. Lack of access to all these affects the economic status of individual and the state in general and also may lead to her underdevelopment.

\section{THE POLICIES OF POVERTY AND POVERTY ALLEVIATION PROGRAMME IN NIGERIA}

The citizens have judge the progress and performance of various governments mainly on its achievements on the economic front. In turn, every government since independence has regarded economic development and poverty reduction as a matter of great urgency. This was intensified by the realization that unfulfilled economic promises constitute a threat to political stability. From the colonial period to this our contemporary time different policies are adopted in efforts to alleviate poverty in Nigeria by various governments. Such policies include The Marketing Board and Farm Settlement Schemes, the pragrammes are designed to fix reasonable price for export crops and improving rural income and welfare, youth developing their farm holding. The National Accelerated Food Development Programme (NAFDP). The programme was aimed to reduce the massive importation of consumable items including food and poultry products. Operation Feed We Nation (OFN) was launch to redress agricultural related problems under specialized institution such as Agricultural Development Programme (ADP) as a World Bank's Integrated Rural Development Approach so as to improve the standard of low income earner resident in the rural areas through farm inputs, The Green Revolution Strategies (GRA), the strategy is a tool of rural class formation and differentiation and is capital intensive (Alanana,2006:76), The River Basin And Rural Development Strategy (RBRDS) this is irrigation base strategy and aimed to arrest the effect of drought and reduce dependence on the importation of goods, Import Substitution Industrialization Strategy For Agriculture (ISI) the strategy was geared towards improving the performance and productivity of local industries particularly sugar production. National Directorate of Employment (NDE) was to solve the problem of mass unemployment, Directorate of Food, Road and Rural Infrastructure (DFRRI), Family Support Programme (FSP), People's Bank of Nigeria (PBN) to provide micro credits. Community Bank $(\mathrm{CB})$ was established as a failure of people bank as a micro credit institution. The community bank was to integrate community development associations and traditional saving system to actualize the aspiration of the rural people in alleviating their poverty. And Family Economic Advancement Programme (FEAP). Mass Mobilization for Social Justice and Economic Reconstruction aimed to mobilize and encourage participation of entire populace in the efforts at revamping the economy. Better Life for Rural Women (BLRW) and the Expanded Programme on Immunization (EPI). These were to improve the better life of rural women and to cater for the health of the rural people. The essence of these policies and programme is to ensure food self-sufficiency and provision of necessary infrastructural facilities that will stimulate economic activities especially in rural areas that will in return enhance incomes and improve living 
conditions of the poor. As part of the measure, the government in 1997 intensified its commitment to address poverty problem with the policy of Community Action Programme for Poverty Alleviation (CAPPA) aimed to improve the conditions of the poor through a targeted, costeffective, demand-driven and promptly delivered programme. The programme also expected to improved productivity and nutritional status of the poor through skills, household, food security and health practices.

To improve effective performance of the programme the democracy government in 1999 comes up with the programme National Poverty Eradication Programme (NAPEP). The programme was geared to eliminates youth unemployment, to provide infrastructural facilities and social services to the rural areas . these come under the following programmes: Youth Empowerment Scheme (YES), Rural Infrastructural Development Scheme (RIDS), and Social Welfare Services Scheme (SOWESS). Rice and cassava initiative was also part of the regime effort to meet with the basic objectives of the Millennium Development Goals (MDGs) of eradicating extreme poverty, hunger and food security. The 7ponits agenda of President Musa Ya'adua after he took over the mantle of leadership was another programme to alleviate poverty. These agendas include the provision of power and energy, food security, wealth creation, transportation, land reforms, security and education. But in spite of huge amount of money invested into the programmes less was achieved do to the fact that the progromme was politicized and hijacked by the elite class. The programme also lack consistency, poor funding and seriousness in solving the problems of poverty in Nigeria (Uke, 2012).

From the above policies and programme by the government in their desired to alleviate poverty by total annual budget has not shown serious commitment in their quest to do so. This facts have been established in the work of Osansa (2001) who argued that the policies those not portray seriousness in eradicating poverty in Nigeria using the blow tables.

\begin{tabular}{|l|l|l|l|l|l|}
\hline YEAR & BLP/FSP/FEAP & NDE & DFRRI & PBN & TOTAL \\
\hline 1990 & N/A & $0.26 \%$ & $0.75 \%$ & $1.86 \%$ & $2.87 \%$ \\
\hline 1991 & $1.36 \%$ & $0.37 \%$ & $0.39 \%$ & N/A $\%$ & $2.12 \%$ \\
\hline 1993 & $0.09 \%$ & $0.13 \%$ & $0.31 \%$ & $0.43 \%$ & $0.96 \%$ \\
\hline 1994 & $0.55 \%$ & $0.36 \%$ & $0.11 \%$ & $0.63 \%$ & $1.65 \%$ \\
\hline 1997 & $2.29 \%$ & N/A & N/A & $0.09 \%$ & $2.38 \%$ \\
\hline 1999 & $0.4 \%$ & N/A & N/A & $0.2 \%$ & $0.6 \%$ \\
\hline
\end{tabular}

Source of data: Osansa (2001)

From the table above poverty alleviation expenditure as percentage of total annual budget of 1990 stood at $2.87 \%$. In 1991 the percentage decreases to $2.12 \%$ and $0.96 \%$ in 1993 . Notwithstanding, in 1994, it rose to insignificant level of $1.65 \%$ and $2.38 \%$ in 1994 and 1997 then finally dropped down to a ridiculous level of $0.6 \%$. The poverty alleviation expenditures have been affected by the serious troubles of inconsistence in terms of application and sustainability. Going by Osansa (2001) analysis using table, there is a growing shift of increase in the poverty alleviation expenditures in 1990 of about $2.87 \%$ and experiences decrease in $1991 / 1993$ of about $2.12 \%$ to $0.96 \%$, eventually raise shapely in $1994 / 1997$ of about $1.65 \%$ to $2.38 \%$ and drastically dropped to $0.6 \%$ in 1999 . However, Osansa (2001) further argued that if this situation were compared with poverty trends in Nigeria it would be observed that an inverse correlation exists.

TRENDS OF POVERTY IN NIGERIA

\begin{tabular}{|l|l|l|l|}
\hline YEAR & $\begin{array}{l}\text { POVERTY LEVEL } \\
\%\end{array}$ & $\begin{array}{l}\text { ESTIMATED } \\
\text { POPULATION(MILLION) }\end{array}$ & $\begin{array}{l}\text { POPULATION IN } \\
\text { POVERTY(MILLI } \\
\text { ON) }\end{array}$ \\
\hline 1980 & 27.2 & 65 & 17.7 \\
\hline 1985 & 46.3 & 75 & 34.7 \\
\hline 1992 & 42.7 & 91.5 & 39.2 \\
\hline 1996 & 64.6 & 102.3 & 76.1 \\
\hline
\end{tabular}

Source of data: Osansa (2001) 
The table shows the trends of poverty between 1980 and 1996. Viewing from 1980 to 1996, as observed the percentage level of poverty was at increase from $27.2 \%$ to $64.6 \%$ respectively in line with the estimated populations. As a matter of fact, this shows lack of serious commitments by the government in their various policies to alleviate poverty amongst its citizens because decrease in total annual budget of poverty alleviation expenditure increases the level of poverty in Nigeria. Following this unprecedented increase of $64.6 \%$, of the trends of poverty, there is every possibility by 2001 the trends of poverty would close to $70 \%$ (Osansa, 2001).

We can see from the table above, that the Nigerian leader were no ready to push out poverty because of their self-fish interest. As Odejide (1997:372) asserted that the programmes have not been targeting the poor and as such elites became the most beneficiaries. The programmes have only succeeded in creating awareness rather than implementation. The political will and zeal needed for alleviating poverty are not in our leaders. These affect the success of all the policies established by regimes. Most of these programmes have achieved little or no success Obansa (2001). Many proportions of people continue to live in abject poverty.

\section{POLITICAL DEMOCRACY AND POVERTY IN NIGERIA DEVELOPMENT}

The Nigeria political democracy which subscribed to fundamental freedom, equity, and justice in terms of power, resource distribution and guaranteed access ad opportunities to all of its citizens has failed in providing the desired potentials as all subscribed to. This comes along way of the increasing poverty level of its citizens. Many, who never believed they would lose their homes, be in debt, and now stand in line for food, are facing reality of abject poverty.

The political democracy in Nigeria lack merit in terms establishing equity and political balances particularly the policies adopted by the political leaders. Most of the policies lack direction, transparency and accountability particularly in poverty alleviation policies. The political leaders make policies that increase the suffering and starvation among its people. They are more of accumulating country's wealth for their own benefit rather than to alleviate poverty among its people. The political leaders are corrupt at all level of governance. According to transparency international's 2006, corruption index ranked Nigeria more corrupt than 27 out of the 45 African countries. Globally, Nigeria ranked 142 out of 164 countries.

Poverty has a linear relationship with the rate of looting that leaders afflict on their countries particularly Nigeria. Sam Nda- Isaiah In his weekly post, leadership newspaper assert that with the increase of Nigerian economy GDP figures of $\$ 509.9$ billion as against South Africa's of $\$ 353$ billion, Nigeria populace remains poor. In line further to his arguments, Lagos alone contributes a quarter to Nigeria's GDP which is larger than the economies of Kenya, Libya, Ghana and Tunisia. The Nigerian economy had been a victim of gross abuse and wasteful diversion of resources that could have been used to foster virile and viable development process through corruption. This becomes the factor that made the series of the programmes to remain a toddler without direction.

Corruption is an endemic problem in the political system and constitutes a major challenge to democratic governance. Corruption is responsible for poverty and poverty is responsible for bringing our young generational people into the menace of armed robbery and others organized crime, drugs, child abuses, street begging, road hawking and other related social vices. These activities has now becomes normal way of living. It has even considered as an alternative for survival. Nigeria as a largest African economy remains the highest incidence of poverty.

The political leadership through its policies and attitude of its individual members to private accumulation of wealth has the power to develop or ruin an economy. A good political leader is link with goal orientations through its policies that will improve the national welfare of its citizens. Osagie ( $2007: 2$ ) argued that "a leader without goal is a mere clown in a circus; at best, he is a pawn in the chess board of power politics". The political leaders in Nigeria are self-centered, having only the goal of satisfying themselves and their immediate families thereby trapping its people into abject poverty.

Most of these policies become agents of rural class formation and differentiation where its implementation benefit only ex-bureaucrat, army officers, politicians, businessmen and traditional 
rulers (Alanana, 2006:74). The policies are colonial legacy for the continuation of exploitation and dependency.

The adoption of SAP at 80 s by the past military government as part of the policy meant to correct the policy distortions and structural imbalances in the economy along way to reduce the poverty level of Nigerians. The policy has further increase rate of poor people in the country. The country were incorporated into national development plan and financed by loans from the industrial countries with the conditions such as privatization and commercialization, foreign trade liberalization, devaluation of currencies etc. The federal government injected the sum of N494.9 million as a package to ameliorate the social cost of structural adjustment to provide employment opportunities, improve health care delivery, as well as transport difficulties (Ifamose , 2001). instead of the policy to reduce the "pains" of adjustment but increase the "pains" of adjustment of the economic crises in Nigeria, it continued to disintegrate the African and Nigeria economy. The number of poor people is at increased, the gap between the rich and the poor has become widened and the migration also become higher ( Ifamose , 2001). Non-African country that achieved the policy implementation of the SAP rather accumulated more debt that resulted in serious economic crises in the region. Virtually all the programmes failed as a result of lack of proper coordination, consistency, focus and adequate mechanism at implementation.

\section{CONCLUSION AND RECOMMENDATIONS}

In Nigeria context, poverty is generally seen as lack of access to the basic necessities of life. According to country review report (Nigeria) 2008, poverty in Nigeria has declined from over 70 per cent a few years ago to about 54 per cent today. Despite this decline, poverty is the major challenge facing Nigeria. From the statistics Nigeria still remain underdeveloped. As defined by Dudley seer (1972) development is absence or total elimination of poverty, unemployment, and inequality. Until these are adequately address and redress that society cannot claim to be developed. These means that any effort made to get rid of these problems translates to improvement in the quality of life and standard of living of members of a given society. Development enhances democracy. Political democracy cannot be effective in development of the society where there is high level of poverty. This means that without adequate planned poverty alleviation programmme backed by positive political will and determination at implementation the gains of democracy would be elusive.

Nigeria involved substantially in policy reduction in government expenditures on social and public sector with the view of reducing poverty line amongst its citizens but, the policies failed to achieve the goal of poverty reduction because of government's inability to involve the target group - the poor, in their formulation. The programmes supposed to be people oriented programme but many were denied opportunity in term of formulation and implementation. Thus, the programmes are wasteful venture in self-reliant development (Obansa, 2001 and Alanana, 2006:81). The programmes are politically motivated and carry the will and desire of the political elite to have their shares of political contribution. The programme lost its value and continuing to enhance Nigerian dependency.

The governments most take its responsibilities serious as to ameliorate the suffering of its citizens through proper implementation and execution of policy particularly job creation. The policies of government should also reflect the needs and aspirations of the people at all times. To overcome the problem of poverty in the country, we must ad hence to Good governance which includes accountability, transparency, adequate responsibility, participation and total commitment to the rule of law. Lack of these will result to corruption and corruption trailed development and genuine democracy. Greater transparency reinforces accountability and responsibility. The war against corruption should be intensified. One way to achieve it is through the amendment of the laws that established the various anti-corruption agencies - Independent Corrupt Practices Commission (ICPC) and Economic and Financial Crime Commission (EFCC), to free them from the control of executive interference. 
The government must implement social investment policies aimed at equipping the poor with the human capital they need to enable them share in the benefit of development and at the same time they must create a favorable climate for economic growth that will enable the poor to escape from their condition through their own means.

It is important to note that, there is a general loss of confidence in government where majority of its citizens are in abject poverty. This will generate disrespect and rendered government policies ineffective. It will also increases the fragility and vulnerability of members of society to external influences i.e. Boko Haram, political instability, religious crises and other criminal activities in the country. The paper also strongly believes with the policy of former president of Nigeria, General Mohammadu Buhari of war against indiscipline. This is because when human mind is discipline every aspect of governance will perform effectively without hindrance.

\section{References}

[1] Aboyade, O. (1975) On need for an operation specification of poverty in the Nigerian economy. In: poverty in Nigeria. Proceedings of the 1975 annual conference of the Nigerian economic society. Ibadan University press, Ibadan, pp.25-34.

[2] Ajakaiye, D.O. and Adeyeye, V.A.A. (2001) "Concepts, Measurement And Causes Of Poverty", Economic And Financial Review. Vol.3. No. 4.

[3] Ajakaiye, O. (1999) Conceptual and Methodological Alleviation in Nigeria. In: Bullion, A Publication Of The Central Bank of the Nigeria.

[4] Alanana, O. O (2006) Sociology Of Development: An Introduction. Kaduna-Nigeria. Joyce Graphic Printers \& Publishers

[5] Aliyu. A. (2003) "Implementation Progress Report: Background, Structure, Achievements and Problems". A paper presented at a one day special presidential retreat for permanent secretaries.

[6] Barrett, C. (2003) "Rural Poverty Dynamics: Development Policy Implications". Paper Presented At The 25 IAAE, Durham, South Africa, 16, 22 August.

[7] Federal Ministry for Economic Cooperation And Development (1992) With Report On German Government Development Policy, Bonn.

[8] Godwin. D. T. and Otuya, B. (2009) “An Appraisal Of Poverty Reduction Programmes And Their Impact On Human Resources Development In Nigeria” Journal Of Political Studies, Vol. 1., No. 4., Pp13-35.

[9] Human development index, 1999

[10]Ifamose. F.O. (2001) Poverty Alleviation As A Tool For Sustainable Democracy. A Journal Of Development And Society. Vol.1. No. 3. Pp.24-36

[11]Lenin, V.I (1968) Fundamental of Marxism Leninism, Moscow, progress publishers

[12] Mato. K., Jacob. J., Akintola. O. (2011) The Nexus Of Democracy And Development In Nigeria: Myth And Reality In RONPE, Review Of Nigerian Political Economy, Special Edition On Election And Democracy, Vol, 1. No. 11, pp 1-15.

[13] Narayan, D. et al (2000) voice of the poor: crying out for change world bank, New York.

[14] Obadan. M. I. (1997) Analytical Framework for Poverty Reduction: Issue Of Economic Growth Versus Other Strategies In Nigerian Economic Society. In: Poverty Alleviation In Nigeria. A Selected Papers for The 1997 Annual Conference, Nigeria Economic Society 
[15] Obansa S.A.J. (2001) Poverty Alleviation Expenditures and Economic Growth: Lesson to be learnt. In: Journal of Research and Development: A publication of the academic revival initiatives, university of Abuja, Nigeria. Vol. 1. No. 1.

[16]Odejide, A.F. (1997) Breaking the Vicious Circle Of Poverty Among Women In Developing Countries. In: Poverty Alleviation in Nigeria. Selected Papers For The 1997 Annual Conference For Nigeria Economic Society.

[17] Okunmadewa, F. (1997) poverty alleviation in Nigeria. In: Poverty Alleviation in Nigeria. Selected Papers For The 1997 Annual Conference For Nigeria Economic Society.

[18] Olasupo. M. A. (2010) The Imperative And Challenges Of Agenda Setting In Nigeria: Road Map To Vision 20:2020.

[19] Omodia, S.M (2007) Poverty Alleviation and Sustainable Democracy In Nigeria: A Case Study Of Keffi Town In Keffi Local Government Area Of Nasarawa State. Unpublished Ph.D Thesis, University of Abuja.

[20] Osagie. E. (2007) The New Nigerian Economy: From Poverty To Prosperity. Benin- Nigeria. AFBSN Publishers.

[21]Rodney, walter (1972) How Europe Underdeveloped Africa, boggle L'Overtune Publication, London.

[22] Sam Nda- Isaiah. Is Nigeria A Poor Country Of Rich Men Or A Country Of Poor Men? Leadership News Paper. Pp 56 And 49

[23] Seer, O. (1972) Development in a divided world, London: Penguin.

[24] The Nigeria Tribune- $13^{\text {th }}$ February, 2013

[25]Uke. I. I. (2012) The Politics Of Poverty Alleviation In A Democratic Nigeria. (Eds) Alanna. O.O . Studies in Political Sociology.

[26] World Bank (2001) World Development Report 2000/2001 attacking poverty. Oxford University press Inc. New York. 